\title{
Pengaruh Lama Pemanasan Lumpia Basah \\ Kemas Non Vakum Terhadap Tpc, Ph, Aw dan Sensori Selama Penyimpanan Suhu Ruang \\ Sutiko ${ }^{\bowtie}$, Adi Sampurno, A Nani Cahyanti, Dewi Larasati \\ Jurusan Teknologi Hasil Pertanian, Fakultas Teknologi Pertanian, Universitas Semarang, Indonesia
}

DOI: http://dx.doi.org/10.26623/jtphp.v13i1.1845

\section{Info Artikel}

Sejarah Artikel:

Disubmit 6 Mei 2020

Direvisi 28 Mei 2020

Disetujui 2 Juni 2020

\section{Keywords:}

Aw; Heating; Lumpia; $p H$;

Sensory; Total Plate Count

\begin{abstract}
Abstrak
Penelitian ini bertujuan untuk mengetahui jumlah Total Plate Count (TPC), pH, Aw dan sensori pada lumpia basah kemas non vakum dengan berbagai lama pemanasan. Hasil penelitian ini diharapkan dapat memberikan informasi ilmiah kepada produsen lumpia basah dan masyarakat tentang pemanasan sebagai salah satu cara untuk memperpanjang umur simpan pada lumpia basah. Rancangan percobaan yang digunakan adalah Rancangan Acak Lengkap (RAL) dengan 4 perlakuan dan diulang sebanyak 5 kali, yaitu perlakuan tanpa pemanasan (P1), lama pemanasan 5 menit (P2), lama pemanasan 10 menit (P3), dan lama pemanasan 15 menit (P4) pada penyimpanan suhu ruang. Data yang diperoleh dianalisis dengan menggunakan ANOVA, dan apabila ada perbedaan akibat perlakuan dilanjutkan dengan uji Duncan Multiple Range (DMRT) pada taraf 0,05. Hasil penelitian menunjukkan perbedaan nyata terhadap TPC, $\mathrm{pH}$ dan Aw, namun tidak berbeda nyata terhadap sensorinya. Semakin lama pemanasan pada lumpia basah kemas non vakum menunjukkan TPC mengalami penurunan, $\mathrm{pH}$ mengalami kenaikan dan $\mathrm{Aw}$ mengalami kenaikan, sedangkan semakin lama penyimpanan (sampai hari ke-4) menunjukkan TPC mengalami kenaikan, $\mathrm{pH}$ mengalami penurunan, dan Aw mengalami kenaikan
\end{abstract}

\begin{abstract}
This study aims to determine the number of Total Plate Count (TPC), $p H, A w$ and sensory in nonvacuum packed wet spring rolls with various heating times. The results of this study are expected to provide scientific information to wet lumpia producers and the public about heating as one way to extend the shelf life of wet spring rolls. The experimental design used was a Completely Randomized Design (CRD) with 4 treatments and was repeated 5 times, namely treatment without heating $(P 1)$, heating time 5 minutes (P2), heating time 10 minutes (P3), and heating time 15 minutes (P4) at room temperature storage. The data obtained were analyzed using ANOVA, and if there were differences due to treatment continued with the Duncan Multiple Range (DMRT) test at the 0.05 level. The results showed a significant difference in TPC, $p H$ and Aw, but not significantly different in the sensor. The longer heating in non-vacuum packed spring rolls shows that the TPC has decreased, the $p H$ has increased and $A w$ has increased, while the longer storage (until the 4th day) indicates the TPC has increased, the $p H$ has decreased, and Aw has increased.
\end{abstract}

\footnotetext{
Alamat Korespondensi: Sutiko, Teknologi Hasil Pertanian, Fakultas

Teknologi Pertanian, Universitas Semarang, Indonesia

E-mail: sutiko@gmail.com 


\section{PENDAHULUAN}

Lumpia adalah makanan yang terbuat dari lembaran tipis tepung gandum yang dijadikan sebagai pembungkus isian yang umumnya adalah rebung, telur, sayuran segar, daging, ikan dan udang (Sufy, 2006). Makanan ini banyak diminati oleh wisatawan yang berkunjung ke semarang sebagai oleh-oleh.

Lumpia terbagi menjadi dua jenis yaitu lumpia basah dan lumpia kering. Lumpia basah biasanya langsung dikemas menggunakan kemasan plastik polietilen (PE) sedangkan lumpia kering harus melewati tahapan penggorengan terlebih dahulu.Dalam produksi pembuatan lumpia saat ini tidak menggunakan bahan pengawet sehingga lumpia tidak bertahan lama dalam penyimpanannya.

Lumpia basah yang dikemas hanya dapat bertahan 1-2 hari dalam penyimpanan suhu ruang sehingga pemasaran lumpia basah juga menjadi terbatas. Produsen belum bisa melayani permintaan dari luar kota karena proses pengiriman terkadang membutuhkan waktu yang lama. Jika hal tersebut dilakukan, maka produk sampai di tangan pelanggan dalam keadaan tidak layak dikonsumsi. Penelitian tentang kualitas fisik dan mikrobiologis lumpia basah yang disimpan menggunakan suhu yang berbeda (Ismail, 2016), menunjukkan bahwa kerusakan produk yang dikemas dengan cara konvensional terutama disebabkan adanya oksigen dan mikroba. Oksigen berperan dalam proses oksidasi komponen bahan pangan, mikroba berperan dalam proses degradasi senyawa nutrisi bahan pangan. Jenis kerusakan yang ditimbulkan oleh mikroba ditandai dengan timbulnya kapang, kebusukan, bau asam, lendir, dan adanya perubahan warna. Kerusakan mikrobiologis dapat berbahaya bagi kesehatan manusia karena racun yang diproduksi mikroorganisme (Muchtadi, 2013).

Berdasarkan hal tersebut akan dilakukan penelitian pemanasan pada produk tersebut. Pemanasan bertujuan untuk menonaktifkan enzim, memperpanjang daya simpan, membunuh organisme seperti bakteri, kapang, khamir yang bersifat patogen dan tidak membentuk spora (Sukasih, 2009). Penelitian dilakukan untuk mengetahui kualitas produk lumpia basah kemasyang dipanaskan. Analisa dilakukan terhadap Total Plate Count (TPC), pH, aktivitas air (Aw) dan sensori lumpia basah selama penyimpanan suhu ruang.

\section{METODE}

\section{Alat dan Bahan}

Peralatan yang digunakan yaitu Erlenmeyer, $\mathrm{pH}$ meter, aw meter, gelas ukur pipet, tabung reaksi, corong, kertas whatman nomer 2, autoclave, Bunsen, incubator, coloni control, mikro pipet, beaker glass, cawan petri, timbangan digital, Sealer, Panci, Kompor Gas, Alat Tulis dan Label.

Bahan penelitian yang digunakan adalah produk olahan Lumpia Basah yang diperoleh dari produsen Tahu Bakso \& Lumpia "Baginda Raja", plastik Low Density Polyethilene (LDPE) ukuran $15 \mathrm{~cm} \times 18 \mathrm{~cm}$, ketebalan 0,8 mm, H2SO4 $50 \mathrm{ml}, \mathrm{NaOH} 25 \mathrm{ml}$, PCA dan larutan BPW $0,1 \%$.

\section{Prosedur Penelitian}

Proses pembuatan lumpia basah kemas non vakum yaitu:

a. Masukkan lumpia basah dalam kemasan (plastic LDPE) masing-masing 2 pcs/pack.

b. Tutup/ segel kemasan menggunakan sealer.

c. Lumpia basah yang telah dikemas kemudian dipanaskan (steam) pada suhu $70{ }^{\circ} \mathrm{C}$ selama $0,5,10,15$ menit.

d. Dinginkan, dan disimpan pada suhu ruang $\left( \pm 28^{\circ} \mathrm{C}\right)$.

e. Pengamatan TPC, $\mathrm{pH}, \mathrm{Aw}$ dan uji sensori dilakukan secara berkala, yaitu pada hari ke- 0 , 2, dan 4. 


\section{Tahapan Pengujian Sampel}

\section{TPC (Total Plate Count) (SNI 2897 ; 2008)}

a. Timbang sampel sebanyak 25 gram kemudian masukkan ke wadah steril.

b. Tambahkan $225 \mathrm{ml}$ larutan BPW $0,1 \%$ steril ke dalam wadah steril yang berisi sampel, homogenkan dengan stomacher selama 1 menit. Ini merupakan larutan dengan pengenceran 101.

c. Pindahkan $1 \mathrm{ml}$ suspensi pengenceran 101 tersebut dengan pipet steril ke dalam larutan $9 \mathrm{ml}$ BPW untuk mendapatkan pengenceran 102. Buat pengenceran 103, 104, 105 dan seterusnya dengan cara yang sama.

d. Masukkan sebanyak $1 \mathrm{ml}$ suspensi dari setiap pengenceran ke dalam cawan petri secara duplo.

e. Tambahkan $15 \mathrm{ml}$ sampai $20 \mathrm{ml}$ PCA yang sudah didinginkan hingga temperatur $45^{\circ} \mathrm{C}$ pada masing-masing cawan yang sudah berisi suspensi. Supaya larutan sampel dan media PCA tercampur seluruhnya, lakukan pemutaran cawan.

f. Inkubasikan pada temperatur $35^{\circ} \mathrm{C}$ selama 24 jam dengan meletakkan cawan pada posisi terbalik.

g. Hitung jumlah koloni pada setiap seri pengenceran dengan menggunakan coloni control. Dalam perhitungan jumlah total koloni mikroba 30-300, jika tiap cawan petri melebihi 300 koloni mikroba maka dianggap tidak terhitung.

\section{Derajat Keasaman (pH) (AOAC, 2005)}

a. Timbang sampel yang telah dihaluskan sebanyak $10 \mathrm{gr}$ dan dihomogenkan menggunakan mortar dengan $20 \mathrm{ml}$ aquades selama 1 menit.

b. Kalibrasi pH meter menggunakan larutan buffer $\mathrm{pH} 4$ dan $\mathrm{pH} 7$.

c. Tuangkan ke dalam beaker glass $10 \mathrm{ml}$, kemudian diukur $\mathrm{pH}$ nya menggunakan $\mathrm{pH}$ meter.

d. Sebelum $\mathrm{pH}$ meter digunakan harus ditera kepekaan jarum penunjuk dengan larutan buffer. Besarnya $\mathrm{pH}$ bisa dilihat setelah jarum skala konstan kedudukannya.

\section{Aktifitas Air (Aw) (Susanto, 2009)}

a. Siapkan aw meter yang sebelumnya sudah dikalibrasi dengan menggunakan larutan $\mathrm{BaCl} 2$, selama 24 jam.

b. Sample lumpia basah dimasukkan ke dalam wadah, kemudian wadah ditutup dengan aw meter.

c. Pembacaan skala aw meter dilakukan setelah 3 jam pengukuran (Sample jangan terlalu banyak, agar tidak mengganggu alat). Aktivitas air dapat ditentukan dengan rumus : Aw $=$ Skala $+[($ suhu $\left.\left.200^{\circ} \mathrm{C}\right) \times 0,002\right]$

\section{Tingkat Kesukaan Warna (Rahayu, 1998)}

Uji sensori warna lumpia basah dilakukan menggunakan metode uji hedonik. Tingkat kesukaan panelis terhadap produk ditunjukkan dengan memberikan nilai 1-7 seperti spesifikasi berikut :

1 : sangat tidak suka

2 : cukup tidak suka

3 : sedikit tidak suka

$4:$ netral

$5:$ suka

6 : cukup suka

7: sangat suka

Uji hedonik terhadap warna dilakukan dengan metode uji sensori menggunakan 50 panelis. 


\section{HASIL DAN PEMBAHASAN}

\section{TPC (Total Plate Count)}

Perbedaan perlakuan lama pemanasan berpengaruh nyata $(p<0,05)$ terhadap TPC lumpia basah kemas non vakum dan setelah di uji lanjut DMRT pada taraf $5 \%$ menghasilkan beda nyata antar perlakuan. Hasil uji TPC lumpia basah kemas non vakum dapat dilihat pada Tabel 1.

Tabel 1. Rerata nilai Log TPC lumpia basah

\begin{tabular}{|l|l|l|l|}
\hline \multirow{2}{*}{ Perlakuan } & \multicolumn{3}{|c|}{ TPC (Log CFU/gr) } \\
\cline { 2 - 4 } & hari ke-0 & hari ke-2 & hari ke- 4 \\
\hline 0 menit & $5.71 \mathrm{a}$ & $5.99 \mathrm{a}$ & $7.01 \mathrm{a}$ \\
\hline 5 menit & $5.31 \mathrm{ab}$ & $5.66 \mathrm{a}$ & $6.51 \mathrm{ab}$ \\
\hline 10 menit & $4.91 \mathrm{~b}$ & $5.17 \mathrm{~b}$ & $6.30 \mathrm{ab}$ \\
\hline 15 menit & $3.72 \mathrm{c}$ & $4.77 \mathrm{~b}$ & $5.97 \mathrm{~b}$ \\
\hline
\end{tabular}

Keterangan : angka yang ditandai notasi huruf yang berbeda pada kolom yang sama menunjukkan beda nyata $(\mathrm{p}<0,05)$.

Tabel 1 menunjukkan bahwa pada penyimpanan hari ke-0, 2, dan 4 nilai TPC berbeda pada setiap perlakuan yang diberikan. Semakin lama waktu pemanasan semakin menurun total TPC- nya dan semakin lama penyimpanan total TPC-nya semakin naik. Hal ini sesuai dengan pendapat Sukasih (2009), bahwa tujuan pemanasan adalah untuk menonaktifkan enzim-enzim, memperpanjang daya simpan, membunuh organisme seperti mikroba, kapang dan khamir yang bersifat patogen dan tidak membentuk spora.

Berdasarkan Standar Nasional Indonesia (SNI), produk makanan semi basah memiliki ambang batas total plate count (TPC) sebesar 1 x $106 \mathrm{CFU} /$ gr atau Log 6 CFU/gr, jadi sampai pada penyimpanan hari ke-2 total TPC masih berada dibawah ambang batas maksimum SNI.

\section{Derajat Keasaman (pH)}

Perbedaan perlakuan lama pemanasan berpengaruh nyata $(\mathrm{p}<0,05)$ terhadap $\mathrm{pH}$ lumpia basah kemas non vakum dan setelah di uji lanjut DMRT pada taraf 5\% menghasilkan beda nyata antar perlakuan. Hasil uji pH lumpia basah kemas non vakum dapat dilihat pada Tabel 2.

Tabel 2. Rerata nilai $\mathrm{pH}$ lumpia basah

\begin{tabular}{|c|c|c|c|}
\hline \multirow[b]{2}{*}{ Perlakuan } & \multicolumn{3}{|c|}{$\mathrm{pH}$} \\
\hline & hari ke-0 & hari ke-2 & hari ke-4 \\
\hline 0 menit & $6.06 a$ & $5.08 b$ & $4.74 b$ \\
\hline 5 menit & $6.06 a$ & $5.10 b$ & $4.78 b$ \\
\hline 10 menit & $6.16 a$ & $5.24 \mathrm{ab}$ & $4.84 b$ \\
\hline 15 menit & $6.24 a$ & $5.34 \mathrm{a}$ & $5.06 a$ \\
\hline
\end{tabular}

Keterangan : angka yang ditandai notasi huruf yang berbeda pada kolom yang sama menunjukkan beda nyata $(\mathrm{p}<0,05)$

Tabel 2 menunjukkan bahwa bahwa pada pengamatan hari ke-0 menunjukkan hasil yang tidak berbeda nyata, sedangkan pada pengamatan hari ke-2 dan ke-4 menunjukkan berbeda nyata. Semakin lama pemanasan maka $\mathrm{pH}$ akan semakin meningkat tapi semakin lama penyimpanan $\mathrm{pH}$ semakin 
menurun. Kenaikan $\mathrm{pH}$ diduga disebabkan karena perlakuan menggunakan metode steaming. Pada pemanasan menggunakan metode steaming akan terjadi proses oksidasi lemak, aldehid dan asam lemak bebas pada bahan pangan sehingga dapat menyebabkan kenaikan pada $\mathrm{pH}$ (Sudjarwanta, 2015). Mikroba umumnya berkembang baik pada $\mathrm{pH}$ 6-7, sedangkan bakteri bisa tumbuh mulai dari pH 4-7 (Waluyo, 2005).

\section{Aktivitas Air (Aw)}

Perbedaan perlakuan lama pemanasan berpengaruh nyata $(\mathrm{p}<0,05)$ terhadap $\mathrm{pH}$ lumpia basah kemas non vakum dan setelah di uji lanjut DMRT pada taraf 5\% menghasilkan beda nyata antar perlakuan. Hasil uji Aw lumpia basah kemas non vakum dapat dilihat pada Tabel 3.

Tabel 3. Rerata nilai Aw lumpia basah

\begin{tabular}{|c|l|l|l|}
\hline \multirow{2}{*}{ Perlakuan } & \multicolumn{3}{l}{ Aw } \\
\cline { 2 - 4 } & hari ke-0 & hari ke-2 & hari ke-4 \\
\hline 0 menit & $0.83 \mathrm{~d}$ & $0.84 \mathrm{~d}$ & $0.86 \mathrm{~d}$ \\
\hline 5 menit & $0.85 \mathrm{c}$ & $0.86 \mathrm{c}$ & $0.88 \mathrm{c}$ \\
\hline 10 menit & $0.87 \mathrm{~b}$ & $0.88 \mathrm{~b}$ & $0.92 \mathrm{~b}$ \\
\hline 15 menit & $0.91 \mathrm{a}$ & $0.92 \mathrm{a}$ & $0.93 \mathrm{a}$ \\
\hline
\end{tabular}

Keterangan : angka yang ditandai notasi huruf yang berbeda pada kolom yang sama menunjukkan beda nyata $(\mathrm{p}<0,05)$

Hasil uji Aw bahwa semakin lama pemanasan Aw juga semakin meningkat dan semakin lama penyimpanan Aw juga semakin meningkat ini diduga disebabkan oleh faktor perlakuan pemanasan menggunakan metode steaming, karena dengan metode ini lumpia basah menjadi lebih banyak menyerap uap air. Sesuai pendapat Putra (2011) yang mengungkapkan bahwa peningkatan lama pemanasan pada metode steaming menyebabkan peningkatan jumlah air yang terserap, karena air dapat berdifusi ke dalam makanan dan berikatan dengan pati dan protein. Perlakuan pemanasan menyebabkan terjadinya kehilangan struktur granula pati sehingga air masuk ke dalam struktur granula. Dengan berlanjutnya pemanasan, semakin banyak air yang memasuki granula pati dengan mudah dan akan meningkatkan aktivitas air (Aw). Semakin tingginya nilai Aw ini akan menyebabkan mudah sekali mikroba untuk tumbuh (Soeparno, 2009)

\section{Sensori (Kesukaan Warna)}

Perbedaan perlakuan lama pemanasan tidak berpengaruh nyata $(\mathrm{p}>0,05)$ pada penyimpanan hari ke-0 dan ke-2, sedangkan pada penyimpanan hari ke-4 berpengaruh nyata $(\mathrm{p}<0,05)$ terhadap $\mathrm{pH}$ lumpia basah kemas non vakum dan setelah di uji lanjut DMRT pada taraf 5\% menghasilkan beda nyata antar perlakuan. Hasil uji TPC lumpia basah kemas non vakum dapat dilihat pada Tabel 4. 
Tabel 4. Rerata skor kesukaan panelis pada lumpia basah

\begin{tabular}{|l|l|l|l|}
\hline \multirow{2}{*}{ Perlakuan } & \multicolumn{3}{|c|}{ Skor } \\
\cline { 2 - 4 } & hari ke-0 & hari & hari ke-4 \\
\hline 0 menit & $4.48 \mathrm{a}$ & $4.42 \mathrm{a}$ & $3.80 \mathrm{~b}$ \\
\hline 5 menit & $4.64 \mathrm{a}$ & $4.48 \mathrm{a}$ & $3.66 \mathrm{~b}$ \\
\hline 10 menit & $4.90 \mathrm{a}$ & $4.12 \mathrm{a}$ & $4.02 \mathrm{ab}$ \\
\hline 15 menit & $4.86 \mathrm{a}$ & $3.94 \mathrm{a}$ & $4.48 \mathrm{a}$ \\
\hline
\end{tabular}

Keterangan : angka yang ditandai notasi huruf yang berbeda pada kolom yang sama menunjukkan beda nyata $(\mathrm{p}<0,05)$

Tabel 4 menunjukkan bahwa skor rata-rata kesukaan panelis relative sama. Pada pengamatan hari ke-0 skor kesukaan antara 4,48-4,90 yang menunjukkan panelis menyatakan suka, sedangkan pada pengamatan hari ke-2 dan ke -4 skor antara 3,66-4,48 bila dibulatkan rata- rata memilih netral.

\section{SIMPULAN}

Berdasarkan hasil penelitian pengaruh lama pemanasan lumpia basah kemas non vakum terhadap TPC, $\mathrm{pH}$ dan Aw selama penyimpanan suhu ruang dapat disimpulkan bahwa : Semakin lama pemanasan pada lumpia basah kemas non vakum menunjukkan TPC mengalami penurunan, pH mengalami kenaikan dan Aw mengalami kenaikan, sedangkan semakin lama penyimpanan (sampai hari ke-4) menunjukkan TPC mengalami kenaikan, $\mathrm{pH}$ mengalami penurunan, dan Aw mengalami kenaikan.

\section{SARAN}

Berdasarkan hasil penelitian yang dilakukan, perlu dilakukan penelitian lebih lanjut mengenai suhu dan lama pemanasan yang berbeda sehingga dapat ditemukan perlakuan yang tepat untuk memperpanjang umur simpan produk lumpia basah kemas non vakum.

\section{DAFTAR PUSTAKA}

AOAC. 2005. Official Methods of Analysis. 18th edition. Association of Official Analitycal Chemist. AOAC. Washington DC : USA.

Ismail, M. dkk.2016. Kualitas Fisik dan Mikrobiologis Bakso Daging Sapi pada Penyimpanan Suhu yang Berbeda. Jurnal Ilmu Produksi dan Teknologi Hasil Peternakan. IPB. Bogor

Muchtadi, T.R, dan Sugiyono. 2013. Prinsip Proses dan Teknologi Pangan. Afabeta : Bandung. Rahayu, W.P. 1998. Penintun Praktikum Penilaian Organoleptik. Fakultas Teknologi Pertanian Bogor. IPB. Bogor

Soeparno. 2009. Ilmu dan Teknologi Daging. Gadjah Mada University Press.Yogyakarta.

Standar Nasional Indonesia (SNI). 2008. Metode Pengujian Cemaran Mikrobia dalam Daging, Telur dan Susu, Serta Hasil Olahan. Badan Standarisasi Nasional. Jakarta.

Sufy, S. 2006. Kreasi Roti. Jakarta: PT. Gramedia Pustaka Utama

Sukasih, Erni dkk. 2009. Optimasi Kecukupan Panas pada Pasteurisasi Santan dan Pengaruhnya Terhadap Mutu Santan yang Dihasilkan. J. Pascapanen 6(1) 2009: 34-42. Bogor : Balai Besar Penelitian dan Pengembangan Pasca Panen Pertanian.

Waluyo, L. 2005. Mikrobiologi Umum. Malang. Universitas Muhammadiyah Malang Press. 